\title{
A metáfora guerra na comunicação das idéias de HIV/Aids em livros didáticos
}

\footnotetext{
Marta Bellini

Priscila Caroza Frasson
}

\section{Resumo}

Apresenta o exame das figuras de retórica, destacando as metáforas presentes em nove livros didáticos e numa apostila de ciências de ensino médio. A seleção dos livros e do tema - HIV/Aids - foi feita a partir de uma entrevista com roteiro com trinta alunos do ensino médio de uma escola pública de Bandeirantes, Paraná. Esses alunos indicaram o tema HIV/Aids como um dos assuntos que queriam conhecer mais. Para a análise das figuras de retórica dos textos didáticos, a pesquisa fundamentou-se nos estudos de Lakoff e Johnson (2002), Breton (2003) e Reboul (2004). Entre as figuras examinadas destacou-se a metáfora guerra como condutora do modelo conceitual sobre o HIV/Aids. Esta metáfora, segundo as autoras, é imprópria para uma educação preventiva, pois subjuga os leitores/ alunos e professores ao medo e à coerção.

Palavras-chave: figuras de retórica; metáforas; HIV/Aids; livros didáticos.

\section{Abstract}

The war metaphor in the transmission of HIV/ Aids ideas in textbooks

The work presents an analysis of rhetorical figures of speech, with special reference to metaphor, in nine textbooks and a science handout for secondary schools. Choice of books and the HIV/Aids theme were made from a structured interview with thirty secondary school students of a government school in Bandeirantes, State of Paraná, Brazil. Students chose the HIV/Aids theme as a subject matter, which they desired to know more about. Studies by Lakoff and Johnson (2002), Breton (2003) and Reboul (2004) underpinned the analysis of figures of speech in school textbooks. The war metaphor representing the conceptual model on HIV/Aids has been conspicuous among the figures of speech analyzed. From the point of view of the authors of the current research, the above metaphor is inadequate for preventive education since it subjects readers/students and teachers to fear and coercion.

Keywords: figures of speech; metaphors; HIV/Aids; textbooks. 


\section{Introdução}

O objetivo deste artigo é mostrar que as idéias de HIV/Aids, nos livros didáticos, se constituem argumentos fundamentados na metáfora guerra e que esta noção não é interessante para estruturar a conduta e a ação de jovens estudantes diante da epidemia. Apesar de a metáfora guerra ser um conceito presente no cotidiano de nossa cultura (sempre falamos em debate, defender nossa idéia, ataque-defesa, batalha verbal), a idéia guerra para apresentar nos livros didáticos o modo de infecção por HIV/Aids gera uma estratégia de comunicação limitada, pois, nestes livros, trata-se de uma luta em que o vírus quase sempre é o vencedor.

De acordo com Ayres (2002, p.15-16), as estratégias de educação que optam pelo terror não são eficazes à prevenção da Aids. Para ele, "A primeira lição aprendida, logo nos primeiros anos da epidemia, é que o caminho do terror, do susto, de que quanto mais assustadora a propaganda melhor seu efeito preventivo, é extremamente limitado". Longe de conseguir adesão para a prevenção e/ou tratamento, essa forma de educação afastou os jovens, pois "ajudou a gerar e aumentar a discriminação e o preconceito", "desmobilizando os jovens ao associar a infecção do HIV ao sofrimento". "Repita-se aqui Betinho", diz Ayres. "É a possibilidade da vida que nos leva a interagir, construir, planejar, não a certeza da morte."

Como os livros didáticos destinam-se à educação científica dos jovens, poderíamos esperar que, pelo menos, no plano da reconstrução conceitual em sala de aula, estes livros estabelecessem o ensino das noções básicas sobre o funcionamento do HIV/Aids segundo os conhecimentos/modelos científicos dos últimos anos, pois estes modelos são elaborados segundo a metáfora interação. No entanto, os livros didáticos por nós examinados, ao apresentar o vírus HIV e os aspectos da síndrome Aids, optam pelas dimensões bélicas para estruturar o modelo e o funcionamento do HIV/Aids, deixando de lado a idéia de interação dos textos científicos.

\section{A metáfora guerra na situacão de ensino: considẻrações teóricas}

As figuras de retórica ou de linguagem, como chamam os gramáticos, são recursos de estilo ou um meio retórico funcional para "exprimir-se de um modo marcante, com encanto e emoção" (Reboul, 2004, p. 113). Quando recorremos às essas figuras impomos "sentidos" à fala ou escrita, ou seja, impomos nossas idéias, concepções de vida e de mundo àquele que nos lê ou nos ouve. Entre as figuras de retórica, a metáfora apresenta um papel fundamental.

"A essência da metáfora é compreender e experienciar uma coisa em termos de outra" (Lakoff, Johnson, 2002, p. 48-49). Na vida cotidiana as metáforas não são meras palavras ou questões da linguagem. As metáforas são, também, partes dos processos de pensamento. Metáfora significa conceito metafórico.

Os conceitos que governam nosso pensamento não são meras questões do intelecto. Eles governam também a nossa atividade cotidiana até nos detalhes mais triviais. Eles estruturam o que percebemos, a maneira como nos comportamos e o modo como nos relacionamos com outras pessoas. Tal sistema conceitual desempenha, portanto, um papel central de nossa realidade cotidiana. [...] Mas nosso sistema conceitual não é algo do qual normalmente temos consciência. Na maioria dos pequenos atos da nossa vida cotidiana, pensamos e agimos automaticamente, seguindo certas linhas de conduta, que não se deixam aprender facilmente. Um dos meios de descobri-las é considerar a linguagem. Já que a comunicação é baseada no mesmo sistema conceitual que usamos para pensar e agir, a linguagem é uma fonte de evidência importante de como é esse sistema (Lakoff, Johnson, 2002, p. 45-46).

Lakoff e Johnson (2002) classificam as metáforas em estruturais, quando um conceito é estruturado metaforicamente em termos do outro ("debater é combater"), orientacionais ("estou me sentindo para cima hoje", ou "estou down", "ele caiu doente") e ontológicas (metáforas de entidade e de substância, como "A inflação está nos colocando em um beco sem saída", "Há tanto ódio nesse mundo", "aquela foi uma boa pegada", "ele explodiu”). As metáforas nos permitem atribuir sentido às nossas experiências; desse modo, falamos "amor é loucura", "amor é guerra", "amor é uma viagem”, "tempo é dinheiro", "estou para cima”, "debater é guerrear", "administrar 
o tempo" e "pegar uma idéia”, para estabelecer nossas ações cotidianas e para expressar o que estamos pensando.

Um dos conceitos metafóricos presentes no dia-a-dia de nossa vida é o conceito discussão, e, pela metáfora, discussão é guerra. Esta metáfora é presente em nosso cotidiano com uma variedade de expressões, dizem Lakoff e Johnson (2002). Em uma discussão falamos em "ganhar ou perder terreno", "ele atacou todos os pontos fracos de minha argumentação”, "suas críticas foram direto ao alvo”, "destruí sua argumentação”, "ele derrubou os argumentos”. Não é possível, para os autores,

[...] imaginar uma cultura em que as discussões não sejam vistas em termos de guerra, em que não haja ganhadores nem perdedores [...]. Imagine uma cultura em que uma discussão seja vista como uma dança, em que os participantes sejam vistos como dançarinos e em que o objetivo seja realizar uma dança de um modo equilibrado e esteticamente agradável. Nessa cultura, as pessoas perceberiam as discussões de outra maneira, experienciariam as discussões diferentemente. Mas nós, provavelmente, não consideraríamos essa atividade uma discussão: as pessoas estariam fazendo algo diferente (Lakoff, Johnson, 2002, p. 47).

Em suma, para Lakoff e Johnson (2002), as discussões normalmente seguem padrões; a linguagem traduz conceitos e o modo como estruturamos os aspectos do mundo em que vivemos.

Os conceitos são estruturados pelas metáforas e também por outras figuras de retórica (ou linguagem) que dão suporte às metáforas. Lakoff e Johnson (2002, p. 92-93), nesse sentido, descrevem a função referencial da metonímia. Demonstram que esta figura está presente quando atribuímos qualidades humanas a entidades não humanas, como "A inflação roubou minhas economias", "Ele está na dança" (na profissão dança). Está presente, ainda, quando descrevemos a parte pelo todo, como "O automóvel está entupindo nossas estradas” (o conjunto de automóveis). Mas, dizem os autores, "metonímia não é meramente referencial”, pois ela tem "pelo menos em parte o mesmo uso que a metáfora”, como quando falamos "O Times ainda não chegou para a coletiva”. Nesse caso, o Times não substitui o repórter somente, mas enfatiza a instituição.

Outro estudo da metáfora e de outras figuras de retórica é o de Olivier Reboul (2004). Este autor apresenta-nos um interessante estudo de argumentação e nos conduz a uma compreensão bem rigorosa das figuras que compõem o sistema retórico. Destacamos de Reboul (2004), para efeito de nosso artigo, a sinédoque e a hipérbole, que são figuras correntes nos livros didáticos que analisamos. A sinédoque cumpre uma função de proposição universal; designa uma coisa por meio da outra que tem com ela uma relação de necessidade, como a parte pelo todo, a matéria pelo objeto, como o exemplo "cem cabeças por cem pessoas”, sinédoque da parte, ou "cem mortais", sinédoque da espécie (Reboul, 2004, p. 121). A hipérbole é a figura que denota exagero, amplifica ou condensa um argumento (Reboul, 2004, p. 120).

Como destacamos as figuras de retórica nos livros didáticos, para avaliá-los, recorremos ao estudo de Paula Contenças (1999) que trata das funções da metáfora no processo de elaboração de modelos conceituais científicos. Contenças (1999) examinou, nas produções escritas na área de genética de 1953 a 1966, suas construções metafóricas. A autora distinguiu em seu estudo dois tipos de metáforas: as substantivas ou constitutivas e as exegéticas ou pedagógicas. As primeiras aparecem na ciência; são utilizadas pelos cientistas para expressar suas teses teóricas. Estas expressões metafóricas permitem aos cientistas "realizar a tarefa de acomodação da linguagem à estrutura causal do mundo" (Contenças, 1999, p. 73). As segundas desempenham um papel importante na comunicação e explicação das teorias e estão presentes nos livros didáticos (Contenças, 1999, p. 72).

Os conceitos metafóricos nas produções escritas na área da genética são as que conhecemos até hoje: "dupla hélice”, "cadeias polinucleotídicas”, "mapa genético”, molécula "esqueleto” de açúcar, RNA “mensageiro”, “código”, “cópia” como traslado de caracteres "escritos”, "informação” genética, genes estruturais, genes transcritos, letras do código genético, mecanismo de leitura dos genes, dicionário de código de palavras (genéticas). Todas são expressões metafóricas que constituíram as teorias e os modelos conceituais da área. Essas metáforas proporcionaram uma estrutura 
coerente na comunicação, conceitualização e categorização da genética.

A transposição dessas expressões ou conceitos metafóricos para o livro didático significa que as metáforas serão, novamente, acomodadas a um novo universo - o do ensino. As teorias científicas passam, então, por uma reconstrução de sentido; ou seja, um novo discurso é produzido, agora pelo autor do livro didático, o novo criador de metáforas. Desse modo, para Contenças (1999), se nas ciências as metáforas permitem a elaboração das teorias articulando-se a lógica da descoberta com a lógica da justificação/comunicação, nos livros didáticos, devido à exigência da aprendizagem dos alunos, os autores lançam mão das metáforas constitutivas ou das exegéticas (pedagógicas). Nesta tarefa os livros didáticos recriam seu próprio discurso e, se o tema for complexo, estes se afastam dos conceitos metafóricos originais como estratégia pedagógica para conseguir a adesão dos alunos aos temas apresentados.

\section{Por que HIV/Aids em livros didáticos?}

Nos livros didáticos, como vimos com Contenças (1999), as expressões metafóricas são mudadas para adequar o modelo elaborado pelos cientistas ao modelo pedagógico e dele obter adesão dos alunos e do professor na situação de ensino. O tema HIV/Aids nos livros didáticos foi por nós escolhido para o exame das figuras de retórica após uma sondagem com 30 alunos do ensino médio entre 15 a 19 anos de idade, na cidade de Bandeirantes, Paraná, em 2005. O objetivo era conhecer, entre os temas de seus livros didáticos de ciências e de biologia, os que mais geravam dúvidas e/ou curiosidade entre os alunos de ensino médio. De acordo com as respostas obtidas com a aplicação de um questionário com seis perguntas, os 30 alunos apontaram a sexualidade/corpo humano como temas que queriam conhecer melhor, e, entre estes, 20 apontaram a Aids como tema que gostariam de compreender mais.

Optamos, então, por analisar o que os livros didáticos diziam sobre HIV/ Aids, primeiro porque estes livros são os utilizados pelos 30 alunos e, em segundo lugar, porque o tema ganhou, hoje, uma importância vital em termos de educação, adesão e vulnerabilidade. $\mathrm{Ou}$ como disse Sanches (1999), a "Síndrome de Imunodeficiência Adquirida (Aids) é um problema de Saúde Pública que alcançou proporções pandêmicas" e está intimamente ligada à vida sexual de todos nós. Sabemos que a sexualidade é central na nossa vida, e também reconhecemos que, por isso mesmo, é particularmente difícil conseguir adesão para a prevenção da síndrome. Deste modo, quando se fala em HIV/Aids fala-se em enfrentar várias situações cotidianas: entre os profissionais da saúde, cientistas, educadores e todas as comunidades que se preocupam em trabalhar com a adesão e vulnerabilidade diante da Aids, uma vez que o número de pessoas infectadas pelo vírus da imunodeficiência humana (HIV), seu modo de transmissão e seu impacto na sociedade levou a Aids a tomar uma grande dimensão social (Sanches, 1999).

Historicamente, a Aids se constituiu como "doença" estigmatizante de homens homossexuais. A partir de 1986, a proporção de homens homo e bissexuais decresceu de 71,3\% para 24,6\% em 1998 (Sanches, 1999). Hoje sabemos que, no Brasil, ocorreu o que se chama de feminização da Aids; a síndrome cresceu entre mulheres e, também, entre os jovens. Ocorreu expressiva elevação de casos de mulheres infectadas: em 1985 tínhamos 24 homens para uma mulher infectada e em 1999 tivemos dois homens para uma mulher, segundo o Boletim Epidemiológico de Aids de junho de 2004.

A Aids não ocorre mais somente no eixo Rio-São Paulo; aumentou em todos os centros urbanos, inclusive nos centros bem menores e em locais rurais em extratos mais pobres (Sanches, 1999). Segundo Sanches (1999), os dados da Coordenação de DST/Aids-MS até novembro de 1998 indicavam "mais de 95\% dos casos com idade superior a 12 anos"; "aproximadamente $70 \%$ estavam na faixa etária entre 20 e 39 anos”. Indicavam que $77,3 \%$ são homens e $22,7 \%$, mulheres; "a idade entre homens é de 30-34 anos e entre mulheres de 25-29 anos, sugerindo que as mulheres se infectam em idades mais jovens". Em pessoas maiores que 12 anos, a transmissão de HIV ocorreu pela relação sexual em 54,3\% dos casos (Sanches, 1999). 
Como enfatiza Sanches (1999), a prevenção é, ainda, a melhor opção para o controle da epidemia da Aids, e é essencial o entendimento de como a doença é percebida em um contexto cultural para que se possa definir e desenvolver estratégias preventivas. Para nós, em termos educacionais, os livros didáticos podem contribuir para a compreensão da epidemia, todavia, pelo que analisamos, é necessário mudar o contexto de comunicação destes livros. Estes livros, nove ao todo e uma apostila do Curso Positivo, são materiais didáticos usados nas escolas da rede pública e da rede privada da cidade de Bandeirantes, PR, portanto, são aprovados e indicados pelo Ministério da Educação. Estabelecemos como categoria livro mais usado na escola sua disponibilidade nas bibliotecas das escolas, na biblioteca pública municipal, para a consulta e estudo dos professores e alunos, e livros indicados pelos professores, provenientes de suas coleções particulares.

No caso dos livros didáticos utilizados no ensino dos jovens nas escolas de Bandeirantes, embora não sejam livros para educação preventiva, o tema HIV/ Aids exige um especial tipo de comunicação, que, para nós, são: a) uma aproximação aos conceitos mais recentes da teoria sobre a interação HIV/Aids elaborada pelos cientistas; b) uma apresentação dos modos de prevenção em uma linguagem que não utilize expressões metafóricas da guerra, porque elas podem provocar a fuga dos leitores e porque estão distantes dos argumentos dos cientistas, como veremos mais adiante neste artigo.

\section{Procedimentos metodológicos: o que dizem os livros sobre HIV/Aids?}

Os livros analisados sob o enfoque das expressões metafóricas e outras figuras de retórica foram:

Livro 1: Biologia Essencial. Sonia Lopes. São Paulo: Saraiva, 2003.

Livro 2: Biologia. José Arnaldo Favaretto e Clarinda Mercadante. São Paulo: Moderna, 2003. Volume único.
Livro 3: Biologia. José Luiz Soares. São Paulo: Scipione, 1999. Volume único.

Livro 4: Biologia. Albino Fonseca. São Paulo: Cia. Editora Nacional, 1999.

Livro 5: Biologia. Wilson Roberto Paulino. São Paulo: Ática, 2003.

Livro 6: Biologia - De olho no mundo do trabalho. Sídio Machado. São Paulo: Scipione, 2003.

Livro 7: Fundamentos da Biologia Moderna. José Mariano Amabis e Gilberto Rodrigues Martho. São Paulo: Moderna, 1998.

Livro 8: Biologia integrada. Luiz Eduardo Cheida. São Paulo: FTD, 2003.

Livro 9: Biologia. Sérgio Linhares e Fernando Gewandsznajder. São Paulo: Ática, 1993.

Livro 10:Apostila Positivo. Desafios do Conhecimento 1. Curitiba: Posigraf, 2004.

No livro 1, Biologia Essencial de Sônia Lopes, a Aids é caracterizada como doença e não como síndrome (síndrome, um conjunto de sintomas). Os vírus são "encapsulados ou envelopados" e "parasitas intracelulares obrigatórios". A autora descreve os vírus qualificando-os como "envelopes" (metáfora) e "parasitas" (metonímia, espécie pela qualidade), "extremamente simples" (hipérboles). Estes seres extremamente simples injetam seu material genético na célula hospedeira (metáfora), o RNA do vírus comanda a síntese protéica na célula hospedeira e o DNA é transcrito em várias moléculas de RNA. A autora não apresenta uma imagem do vírus HIV, mas somente do bacteriófago. Em suma, para a autora, os vírus são seres extremamente simples que atacam a célula hospedeira, injetam seu material genético e comandam a síntese de seu RNA por meio do DNA da célula hospedeira. A metáfora guerra estrutura o modelo de funcionamento do HIV.

No livro 2, Biologia de José Arnaldo Favaretto e Clarinda Mercadante, os vírus são definidos como os únicos seres vivos que não apresentam organização celular e têm apenas RNA e DNA. Estes são descritos como parasitas intracelulares obrigatórios (metonímia, espécie pela qualidade). Também são chamados de parasitas (metáfora) em "estado temporário de aparente inatividade no interior da célula hospedeira 
como o herpes" (metáfora). Apresentam o HIV, como o vírus que invade os linfócitos humanos e, por meio de seu RNA, pela ação da enzima transcriptase reversa, assume o comando de sua reprodução. Os autores estabelecem para a ação do HIV no corpo humano a mesma metáfora guerra do livro 1.

No livro 3, Biologia, de José Luiz Soares, o vírus HIV é definido como agente infectante de células vivas. Os vírus apresentam estrutura simplíssima (hipérbole). Suas dimensões variam entre $17 \mathrm{~nm}$ (nm é a milionésima parte de um milímetro) e 300 nm (uma molécula de hemoglobina mede 6,4 nm de diâmetro). Define a membrana externa dos vírus como cápsula protéica e o RNA como o miolo de ácido nucléico (metonímia), que pode ser de DNA (vírus do herpes, adenovírus, bacteriófago) ou de RNA (vírus da gripe, poliomielite, Aids e mosaico do tabaco). Os vírus “[...] atacam as células injetando-lhes o seu ácido nucléico” (metáfora guerra).

No livro 4, Biologia, de Albino Fonseca, temos as mesmas definições de vírus dos livros 1, 2 e 3 . O autor trata a Aids como uma síndrome, mas a define como mal recente entre nós. Descreve os linfócitos T4 e como estes atacam os "micróbios invasores”, enquanto que os linfócitos B passam a produzir substâncias denominadas anticorpos. $\mathrm{O}$ autor descreve como o vírus HIV ataca preferencialmente os linfócitos T4, inserindo seu código genético composto de RNA. Após o ataque, o HIV implanta seu código genético no interior dos linfócitos T4, se duplica à custa deles e, finalmente, os destrói, ameaçando, então, o sistema imunológico. As expressões ataca, implanta, destrói são expressões metafóricas da guerra. Quanto à prevenção da Aids, o autor utiliza-se de hipérboles como é importantíssimo medidas de prevenção da contaminação pelo HIV. Ou diz: Com certeza não transmitem o vírus da Aids o ar, as banheiras e privadas, a água das piscinas, os abraços, os beijos sociais na face, na testa e doações de sangue com instrumentos descartáveis. Descreve, assim, uma concepção de prevenção ambígua.

No livro 5, Biologia, de Wilson Roberto Paulino, o HIV é descrito como aquele vírus que invade e destrói os linfócitos T, glóbulos brancos do sangue, essenciais para o funcionamento dos linfócitos B, produtores de anticorpos, e para a atividade fagocitária de outros glóbulos brancos. Para o autor, a Aids torna-se mais evidente em um corpo humano quando surge o sarcoma de Kaposi, que é um tumor canceroso, o que, sabemos, não é correto. No texto do livro, a metáfora guerra é, assim, também presente: "O HIV invade e destrói os linfócitos T"; "Assim, a destruição dos linfócitos T provoca a [...]"; "Nesta situação, o organismo fica exposto ao desenvolvimento de inúmeras doenças consideradas 'oportunistas"”. O autor recorre à hipérbole para designar o tamanho dos vírus: "Os vírus são extremamente pequenos". As metonímias são: "Os vírus são conhecidos como parasitas intracelulares obrigatórios" (figura de espécie pela qualidade); "[...] há a representação dos bacteriófagos ou fagos, parasitas de certas bactérias" (figura o ser pela espécie); "Os vírus são parasitas de microrganismos [...]” (figura o ser pela espécie). Quanto à prevenção, indica o uso do preservativo e a esterilização de materiais cirúrgicos e odontológicos.

O livro 6, Biologia - de olho no mundo do trabalho, de Sídio Machado, descreve o HIV/Aids como vírus com RNA, que, pela ação da enzima transcriptase reversa, sintetiza DNA. Indica os dois tipos de vírus da Aids, o HIV-1 e o HIV-2. Ambos destroem o linfócito $\mathrm{T}$ auxiliar, a principal célula do sistema imunológico humano. O HIV liga-se ao receptor CD4 na superfície do linfócito $\mathrm{T}$ auxiliar e libera o nucleocapsídeo para o interior da célula, e o nucleocapsídeo se desfaz, liberando as duas fitas de RNA e as enzimas do HIV. Descreve a evolução da Aids e as doenças provocadas por microrganismos oportunistas: pneumonias, candidíase oral, toxoplasmose, herpes e tuberculose, além dos tumores malignos. Machado também utiliza a metáfora estrutural guerra: “[...] que era capaz de infectar bactérias e, por isso, ficou conhecido como vírus bacteriófago, que significa "vírus comedor de bactérias"; "Os vírus são entidades infecciosas que não possuem [...]”; "O DNA do vírus assume o comando do citoplasma da bactéria”; "Na última fase, a enzima endolisina produzida pelo vírus provoca a destruição ou lise da bactéria". "Transcorridos 30 minutos, há liberação de 100 novos vírus que irão parasitar outras bactérias"; "o HIV-1 e o HIV-2, e ambos destroem o linfócito T auxiliar”; "A enzima integrase insere o DNA viral”; “[...] pode ficar dormente (lisogenia) ou pode fazer o ciclo lítico, reproduzir-se rapidamente e destruir o linfócito T auxiliar”; “Transcorridos 30 
minutos, há liberação de 100 novos vírus que irão parasitar outras bactérias"; "O DNA do vírus incorpora-se ao DNA bacteriano e permanece dormente sob a forma de provírus".

O livro 7, Fundamentos da Biologia Moderna, de Amabis e Martho, expõe o HIV/Aids como retrovírus que se reproduzem na célula. O livro descreve a ação da transcriptase reversa; a mensagem genética do RNA viral é transcrita para uma molécula de DNA. O HIV ataca os linfócitos T, causando a síndrome da imunodeficiência adquirida. Para os autores, a Aids é uma doença letal, ainda sem cura, que se disseminou rapidamente pelo mundo a partir de 1981. Dizem os autores: "Um único vírus, ao invadir uma célula, pode assumir o comando das atividades celulares"; "Como [os vírus] não possuem a maquinaria necessária para realizar nenhum desses processos, desenvolveram, [...] mecanismos para subverter o funcionamento da célula hospedeira e se reproduzir à custa do metabolismo celular"; "[...] eles inibem o funcionamento do material genético da célula infectada e passam a comandar a síntese de proteínas"; "A transcriptase penetra no núcleo da célula infectada e incorpora-se a um de seus cromossomos"; "O HIV ataca os linfócitos T”. Utilizam a hipérbole para designar a velocidade da interação dos vírus com as células: "No entanto, sua capacidade reprodutiva é assombrosa [...]”; "[...] capaz de produzir, em poucas horas, milhões de novos indivíduos". Predomina no texto a metáfora guerra.

No livro 8, Biologia Integrada, de Luiz Eduardo Cheida, a Aids é apresentada em sua composição, estrutura, funções e reprodução. O autor faz a descrição da forma de transmissão, causas e sintomas da Aids. Para o autor, o vírus pode ficar no fluido vaginal e no sêmen quando é transmitido pela relação sexual. $\mathrm{O}$ vírus $\mathrm{HIV}$ pode ser transmitido diretamente para o sangue de uma pessoa sadia por transfusões ou por agulhas e seringas partilhadas. O HIV ataca as células de defesa do corpo e deixa a pessoa vulnerável a qualquer doença. O autor utiliza a metáfora guerra: "o vírus [...] adere a uma célula, parasita-a e se reproduz"; "Na maturação, os capsídeos formados acoplam-se às novas moléculas de DNA, produzindo novos vírus. Ocorre, posteriormente, a liberação dos vírus da célula infectada”; "[...] todos os lugares onde possam parasitar quaisquer células e causar doenças virais ou viroses"; "[...] não surjam doenças que se aproveitem do corpo já debilitado”. A hipérbole assegura a noção de estrutura simples para o vírus: "[...] sua estrutura é a mais simples que se conhece".

O livro 9, Biologia - Programa Completo, de Sérgio Linhares e Fernando Gewandsznajder, destaca os dois tipos de HIV: o HIV-1 e o HIV-2. De acordo com os autores, os dois tipos de vírus atacam as células T4. Por isso, os doentes de Aids apresentam uma grande vulnerabilidade a infecções por germes chamados oportunistas, que não causam problemas a pessoas com saúde normal. A metáfora guerra conduz os argumentos utilizados pelos autores: "É causada por um vírus que ataca o linfócito T4”; "O sarcoma de Kaposi, que ataca os tecidos dos vasos sangüíneos [...]"; "Finalmente, por atacar também células do sistema nervoso, ele pode causar distúrbios neurológicos inclusive demência”; "Após penetrar na célula, o RNA do vírus"; "podendo atacar e destruir outras células"; “[...] a partir de outro vírus que parasita os macacos verdes"; "O principal modo de transmissão se dá pelo ato sexual. $\mathrm{O}$ vírus pode penetrar através de lesões, cai na circulação e ataca os linfócitos do sangue"; "[...] a mulher contaminada pode passar o vírus para o bebê"; "Suspeita-se que o contágio possa se dar também através da amamentação".

No livro 10, a Apostila Positivo - Desafios do Conhecimento 1, da Editora Posigraf/ AS, há a descrição do vírus HIV; apresenta as formas de contágio, sintomas, complicações, tratamento e profilaxia. A Aids é tratada como doença que destrói parte do sistema imunológico do corpo. Quando o vírus HIV é transmitido, ataca principalmente as células chamadas linfócitos T e os macrófagos. As metáforas mais utilizadas são as estruturais; indicando idéia de guerra: "Atacam todos os seres vivos, especificamente, plantas ou animais e [...]"; "Quando estão fora das células atacadas e, portanto, não estão se reproduzindo, não manifestam nenhuma atividade vital"; "Esta doença destrói parte do sistema”; "[...] suas vítimas se tornam incapazes de se defenderem (sic) de outros agentes etiológicos oportunistas, como certos tipos de [...]"; "[...] o portador do HIV é um transmissor que deve ser orientado para precaver-se e não contaminar ninguém”; "Quando o vírus HIV é transmitido, ataca principalmente”; “[...] 
e ao se produzirem anticorpos para darlhe combate, ficam sem ação diante das transformações que o vírus sofre [...]"; "[...] ao amadurecimento do HIV, fase final do ciclo".

Os dez textos analisados tratam o HIV como estrutura "extremamente" simples; vírus são seres de RNA que são capazes de, por sua evolução, transformar RNA em DNA e realizar sua reprodução. Desse modo, estes seres tão "simples" vencem a guerra contra as células nas quais se hospedam. O esquema conceitual dos 10 livros - há livros com mais informações, outros menos - é o mesmo em termos das expressões que levam à metáfora guerra. Este esquema traduz-se em: "seres simples ou extremamente simples (hipérbole) atacam uma célula (a hospedeira), lançam (ou implantam ou inserem) seu material genético nesta célula e reproduzem". O vírus aparece descrito como onipotente. Se ele (o vírus) pode tudo - o vírus vence a guerra contra o organismo -, se ele sempre vence, ou fugimos desta lição, para que ela não nos atormente, ou deixamos a sexualidade de lado. Sabemos que não é correta esta afirmação, pelo menos para os cientistas. Na secção seguinte vamos indicar, então, como os cientistas comunicam-nos as descobertas sobre o HIV/Aids.

\section{O que dizem os textos científicos: a metáfora interação}

Se não é a metáfora guerra a forma de comunicar a idéia de HIV/Aids nos livros didáticos, qual seria um outro tipo de comunicação do tema? Como dissemos, a idéia de combate entre o organismo humano e um ser "muito simples" traduz-se em um jogo de guerra em que, segundo os livros didáticos, vence o vírus. Para investigar um outro modo de expressão metafórica do tema HIV/Aids, oito textos científicos, descritos nesta seção, acerca da estrutura e funcionamento do HIV, foram examinados. Afinal, destes textos são estruturados outros que servem à finalidade de divulgação científica. Vamos descrever como o tema HIV/Aids é neles tratado e estabelecer qual metáfora estrutura a noção de HIV/Aids.

Em Bicudo (2005) o HIV é descrito como um vírus complexo tanto do ponto de vista bioquímico como evolutivo.
Evolutivamente, o HIV é capaz de interagir com células do sistema imunológico por meio de estratégias de replicação bastante elaboradas. As estratégias de replicação e evolução do HIV são tão organizadas que os cientistas já conhecem, atualmente, nove subtipos de vírus HIV, identificados como A, B, C, E, F, G, H, J e K - todos são produtos de variações genéticas. São vírus parecidos que se diferenciam pela seqüência maior ou menor de genes (Bicudo, 2005).

Não se trata, portanto, de um vírus extremamente simples. Delicato (2005) indica a complexidade da membrana do HIV, em termos de estrutura e funcionamento bioquímico, quando mostra que ele apresenta duas membranas: a externa e a interna membrana. A primeira membrana é lipoprotéica, formada por 72 complexos de glicopreteina ligada aos lipídeos do chamado envelope. Cada complexo apresenta uma glicoproteína, a gpl120, e uma proteína transmembranar, a gpl41, que mudam sua estrutura de acordo com o ambiente. Internamente à membrana do HIV há um envoltório de proteína denominada p17, que delimita o espaço da cápsula protéica formada pelo antígeno denominado p24. No interior dessa cápsula há outro complexo proteína-ácido, formado por duas moléculas de RNA associadas à nucleoproteína denominada p7 e à enzima transcriptase reversa. A partícula viral tem enzimas que processam a replicação do HIV: são a transcriptase reversa, a integrase p12 e a protease p11 (Delicato, 2005).

De acordo com Roitt, Brostoff e Male (2003), o HIV interage com as células T ou linfócitos $\mathrm{T}$ auxiliares (Helper), células que têm a função de controlar a resposta do organismo às infecções. As células $\mathrm{T}$ apresentam em sua superfície uma molécula, a CD4 ou receptor CD4, uma glicoproteína monomérica de $58 \mathrm{kDa}$ (quilodáltons), e o HIV interage exatamente com este receptor CD4, tirando das células T sua capacidade de controlar a entrada e reprodução do HIV.

O mecanismo pelo qual o HIV atinge e destrói os linfócitos ainda não está claramente compreendido. Há vários modelos para explicitar este mecanismo. O modelo mais aceito é o da ligação intracelular entre o receptor CD4 da célula T e a proteína gp120 do HIV (Roitt, Brostoff; Male, 2003). Este modelo é o que apresenta o HIV-1 realizando o processo de adsorção e fusão de sua estrutura com a membrana citoplasmática 
do linfócito. Esta fusão é, na verdade, a interação das proteínas do envelope viral gp120 (glicoproteína) com os receptores da superfície da célula CD4 (receptor), CCR5 ou CXCR4 (co-receptores) dos linfócitos T Helper e das células da linhagem dos macrófagos (Delicato, 2005). A fusão entre HIV e o linfócito provoca a transformação na forma e função das células T. Há, então, mudança nos receptores das membranas do linfócito, ocorrendo, então, a chamada infecção por HIV (Janeway et al., 2002).

Quanto à replicação HIV, este apresenta um genoma com nove genes com longas seqüências terminais repetitivas (LTRs), que se integram ao DNA do linfócito (Janeway et al., 2002). Todavia, $a$ interação entre o RNA do vírus e o DNA do linfócito não é tão fácil de ser realizada. Os linfócitos criam mecanismos para evitar a exportação de transcritos de mRNA processados em seu núcleo. Isso pode ser um problema para o HIV, pois ele depende da exportação de espécies de mRNA não processados para traduzir todas as proteínas virais.

De acordo com Delicato (2005) os estudos sobre o HIV indicam que a replicação viral é dinâmica, e os linfócitos e os vírus interagem em um processo de auto-regulação. Por um lado, os linfócitos reagem ao HIV; por outro, o próprio genoma do HIV "erra” em sua replicação. Ocorre uma pressão seletiva sobre o HIV por mutações pré-existentes exercida por certas drogas ou pelo próprio sistema imunológico que produz anticorpos neutralizantes ou células T citotóxicas.

A capacidade de infecção de um organismo pelo HIV depende dos fatores de risco biológicos e comportamentais; biológicos são aqueles que dizem respeito à concentração do HIV no fluido biológico, integridade e vulnerabilidade da mucosa (anal, oral e vaginal), duração da exposição e amostra viral não transmitida. A transmissão do vírus HIV pode ocorrer pelo ato sexual, sangue e vertical, ou seja, de mãe para filho, por meio de uma infecção durante a gestação, perinatal, pós-natal ou durante o aleitamento. O HIV tem acesso ao organismo pelas mucosas que são ricas em células de Langerhans (células que capturam antígenos e partículas virais). Após 18 horas de infecção, os vírus se encontram em células dendríticas e células $\mathrm{T}$ da mucosa genital e, em poucos dias, detecta-se vírus em linfócitos e monócitos próximos ao local da infecção e, em seguida, nos tecidos linfóides regionais (Delicato, 2005).

Janeway, Travers, Walport e Shlomchik (2002) descrevem que, a partir do momento em que há redução no número de células T CD4 no organismo pela entrada do HIV, pode-se falar em três mecanismos: no primeiro, há a morte direta das células infectadas pelo vírus; no segundo, aumenta a suscetibilidade do organismo; no terceiro, a morte das células T CD4. Quando o número de células T CD4 fica abaixo de um nível crítico, o corpo humano perde a imunidade celular e surgem os sintomas como a febre, sudorese noturna, diarréia e perda de peso. Em seguida, surgem as infecções por uma variedade de agentes oportunistas. Em geral, a resistência do organismo sucumbe à candida oral ou candida albicans e ao mycobacterium tuberculosis. Neste estágio, a contagem de células T CD4 encontra-se normalmente abaixo de 200/İl. Mais tarde, os pacientes podem ter o Herpes zoster, os linfomas e sarcoma de Kaposi ou outras doenças.

Os anticorpos contra o HIV aparecem, no sangue de indivíduos infectados, de 3 a 12 semanas. Este período é denominado de "anela imunológica"; é o período compreendido entre o momento da infecção e o aparecimento de anticorpos anti-HIV em concentração suficiente para permitir a sua detecção pelas técnicas laboratoriais correntes (Manual de condutas, 2000). Os testes utilizados com maior freqüência para a detecção de anticorpos anti-HIV são os ensaios imunoenzimáticos (ELISA $=$ Enzyme-Linked Immunosorbent Assay), por sua facilidade de automação e custo relativamente baixo. Há, segundo o Ministério da Saúde (Manual de condutas, 2000), outras técnicas que detectam diretamente o vírus ou suas partículas e são utilizadas em situações específicas.

Com relação ao tratamento da Aids, desde 1987, usa-se a zidovudina (AZT); é como análogo ao nucleosídeo inibidor da transcriptase reversa, a enzima utilizada pelo HIV. O período ideal para o início da terapia ainda é controverso, mas, geralmente, ocorre quando há uma contagem repetida de células CD4 em torno de 200-400 células/î-1 e em todos os pacientes sintomáticos (Roitt, Brostoff, Male, 2003). Segundo Janeway, Travers, Walport e Shlomchik (2002), já nas duas primeiras semanas após 
o início do tratamento há queda na produção do vírus. Após esse período, a taxa de declínio do vírus é mais lenta.

Atualmente, uma nova classe de medicamentos está sendo utilizada em pessoas com HIV. Souza (2006), no texto "Fuzeon, o primeiro medicamento de uma nova classe anti-HIV denominada inibidores de fusão", descreve como o fuzeon pode inibir o processo de interação da proteína gp 20 do HIV com o receptor CD4 e com os co-receptores CXCR4 ou CCR5 do linfócito.

Para Janeway, Travers, Walport e Shlomchik (2002), o desenvolvimento de vacinas para a prevenção da infecção pelo HIV é um objetivo das pesquisas atuais. Mas este empreendimento encontra obstáculos pela própria natureza da infecção por HIV, pois ele replica e se recombina rapidamente. Outro problema é a capacidade de o HIV persistir em forma latente no organismo. Mas, além disso, há os aspectos éticos: é difícil ou quase impossível conduzir um teste de vacinas sem expor aos riscos do HIV a população vacinada.

Capria (2003) e Lanzarini (2005) questionam a precisão dos "testes da Aids" (Elisa e Western Blot). Dizem que, em pesquisas controladas, há uma percentagem muito elevada de reações cruzadas falsopositivas devido a diferentes fatores do HIV, pois podemos ter pessoas que foram expostas anteriormente à tuberculose, à clamídia sp, à pneumonia, malária e outras 50 doenças que podem dar um resultado "soropositivo". Capria (2003) também afirma que a situação da África é diferente das demais regiões do globo terrestre, sobretudo dos Estados Unidos e da Europa. Para Capria (2003), antes de 1980 o HIV não era incluído como vírus da Aids na África. Somente após 1985 todas as moléstias como febre, diarréia, tosse persistente e perda de peso foram caracterizadas como Aids, distorcendo as estatísticas mundiais de casos de Aids.

Como vemos, a explicação científica do HIV e de aspectos da infecção da Aids não são fáceis de serem apreendidos pela complexidade terminológica, porém os textos que apresentamos nos dão pistas de que a metáfora utilizada pelos cientistas é a da interação. O HIV interage bioquimicamente com os linfócitos e estes, por sua vez (já que não são objetos-recipientes de vírus, como dizem os livros didáticos), reagem ao HIV. A idéia, então, de seres simples que causam uma doença mortal é substituída por interação bioquímica entre um vírus complexo e células, os linfócitos, que são provocadas para reagir.

\section{Conclusão}

Ayres (2002), referindo-se aos modelos educacionais, diz que o Brasil demorou a buscar modelos emancipatórios de educação como o de Paulo Freire. No geral, os modelos de educação preventiva são, diz Ayres (2002, p. 17), "bastante limitados e limitantes". "São modelos, diz Ayres citando Paiva, orientados por uma idéia de comunicação unidirecional, dogmática e autoritária; modelos baseados na idéia de aprendizado como simples aquisição de informação; modelos centrados na modelagem do outro à própria imagem como objetivo da educação preventiva."

Os exemplos de comunicação dos livros didáticos aqui apontados podem ser entendidos como formas de pensar e de falar um tema - o HIV/Aids - de modo limitante à compreensão científica do que são o vírus e a síndrome até o momento. Apesar do esforço dos autores em tratar do tema Aids em uma linguagem palatável aos estudantes de ensino médio, esta retórica - a da guerra - impõe uma via de mão única à compreensão do HIV.

Para os autores dos livros didáticos, o HIV, este "ser extremamente simples", ataca, comanda, prolifera e mata. Para os cientistas a interação entre o RNA do vírus e o DNA do linfócito não ocorre de modo tão brando assim. Os linfócitos criam mecanismos para evitar que o RNA do HIV processe sua replicação (ver Janeway; Travers; Walport; Shlomchik, 2002). A idéia de que esse "ser extremamente simples" traduz-se em uma "doença mortal" (hipérbole, figura do exagero que cria uma antítese) é o raciocínio base dos textos. Não é fácil partilhar desse argumento (seres simples e mortais que entram em guerra com os homens). Então, como fica a adesão aos argumentos ditos científicos dos livros didáticos?

Como estamos falando/argumentando com um auditório de adolescentes, pois os livros didáticos são para alunos de ensino médio, é importante destacar a eficácia da metáfora guerra; esta metáfora pode não resultar em negociação de 
sentido com os jovens. Para nós, a metáfora guerra utilizada nos livros didáticos analisados não permite abertura para a circulação de informações científicas sobre uma epidemia que, cada vez mais, alcança jovens, mulheres, crianças e homens. Como a Aids quase sempre é vinculada aos aspectos mais conservadores da educação, a metáfora guerra não estaria colaborando para afastar os jovens do universo conceitual e afetivo dos alunos? Se esta idéia ficar distante destes universos, o espaço para a negociação de significados também ficará restrito. Nessa situação de distanciamento, no máximo os alunos aprendem uma fórmula que não tem qualquer significado em suas vidas: vírus simples que provocam uma doença mortal. O discurso sobre HIV/Aids veiculado, nas escolas, pelos livros didáticos de modo reducionista e não explícito não garante uma adesão racional e, de fato, preventiva entre os jovens. Ou, como diz Ayres (2002), “quem pensa a prevenção pensa a subjetividade, a significação, a interação, a dinamicidade”. Para isso, temos que caminhar para além da guerra entre os vírus e os humanos.

\section{Referências bibliográficas}

AYRES, José Ricardo Carvalho Mesquita. Práticas educativas e prevenção de HIV/Aids: lições aprendidas e desafios atuais. Revista Interface, v. 6, n. 11, p. 11-24, 2002.

BRETON, P. A argumentação na comunicação. 2. ed. Bauru: Edusc, 2003.

BICUDO, Francisco. Os truques do HIV. Boletim Agência Fapesp on line, 16/3/2006. Disponível em:http://www.agencia.fapesp.br/boletim_dentro.php?data\%5Bid_materia_boletim\%5D=5216. Acesso em: 16 março 2006.

CAPRIA, M. M. Scienza e Democrazia. 1. ed. Liguori Editore, 2003.

CONTENÇAS, P. A eficácia da metáfora na produção da ciência. O caso da Genética. Lisboa: Instituto Piaget, 1999.

DELICATO, L. S. O papel dos co-receptores CCRS e CXCR4 na infecção pelo vírus HIV. Monografia - Fundação Faculdades Luiz Meneghel, Bandeirantes, Paraná, 2005.

FERNANDES, João Cláudio. Práticas educativas para a prevenção da HIV/Aids: aspectos conceituais. Caderno de Saúde Pública, Rio de Janeiro, v. 10, n. 2, p. 171-180, abr./ jun. 1994.

GIACOMOZZI, Andréia Isabel; CAMARGO, Brigido Vizeu. Eu confio no meu marido: estudo de representação social de mulheres com parceiro fixo sobre prevenção da Aids. Revista Psicologia: Teoria e Prática, São Paulo, v. 6, n. 1, p. 31-44, jan./jun. 2004.

JANEWAY, C. A. et al. Imunobiologia. O sistema imune na saúde e na doença. 5. ed. São Paulo: Artmed, 2002.

LAKOFF, George; JOHNSON, Mark. Metáforas de vida cotidiana. Campinas: Mercado das Letras/EDUC, 2002.

LANZARINI, J. HIV não existe. É possível? Muitos acreditam que sim. Revista Viração e Projeto Agente Jovem, Porto Alegre, 2005.

MANUAL DE CONDUTAS. Controle de infecções e a prática odontológica em tempos de Aids. Brasília, Ministério da Saúde, 2000.

MINISTÉRIO DA SAÚDE. Disponível em: < http://dtr2004.saude.gov.br/dab/saudebucal/ publicacoes/manual_odonto1.pdf>. Acesso em: 30 novembro 2005. 
PAIVA, Vera. Sem mágicas soluções: a prevenção do HIV e da AIDS como um processo de Emancipação Psicossocial. Divulgação em Saúde para Debate, Rio de Janeiro, n. 27, p. 58-69, ago. 2003.

POLLACK, Michael. Os homossexuais e a Aids. Sociologia de uma epidemia. São Paulo: Estação Liberdade, 1990.

REBOUL, Olivier. Slogan. São Paulo: Cultrix, 1975.

Introdução à Retórica. 2. ed. São Paulo: Martins Fontes Editora, 2004.

ROITT; BROSTOFF; MALE. Imunologia. 6. ed. São Paulo: Manole, 2003.

SANCHES, Kátia Regina de Barros. A Aids e as mulheres jovens: uma questão de vulnerabilidade. Tese (Doutorado) - Fundação Osvaldo Cruz, Escola Nacional de Saúde Pública, 1999. 143 p.

SOUZA, Marcos Vinícius Nora. Fuzeon, o primeiro medicamento anti-HIV denominada inibidores de fusão. Revista Brasileira de Farmácia, v. 86, n. 3, 2005.

Marta Bellini, professora doutora do Departamento de Fundamentos da Educação e Mestrado em Educação para a Ciência e Ensino de Matemática da Universidade Estadual de Maringá (UEM).

martabellini@uol.com.br

Priscila Caroza Frasson, professora mestre do Departamento de Saúde e Educação da Fundação Faculdades Luiz Meneguel, Bandeirantes, Paraná.

Recebido em 19 de junho de 2006.

Aprovado em 6 de outubro de 2006. 